\title{
25 Research Square \\ The emergence of the national medical assistance scheme for the poorest in Mali
}

\section{Laurence Touré ( $\nabla$ chat@afribonemali.net)}

Valery Ridde

Institut de recherche pour le developpement https://orcid.org/0000-0001-9299-8266

\section{Research}

Keywords: Social Policy, Agenda-Setting, Emergence, Equity, Poorest, Universal Health Care, Mali, Africa

Posted Date: March 5th, 2020

DOl: https://doi.org/10.21203/rs.3.rs-16164/v1

License: (c) (1) This work is licensed under a Creative Commons Attribution 4.0 International License. Read Full License

Version of Record: A version of this preprint was published at Global Public Health on December 4th, 2020. See the published version at https://doi.org/10.1080/17441692.2020.1855459. 


\section{Abstract}

Background : Universal health coverage $(\mathrm{UHC})$ is now high up the international agenda. There are still major needs to be met in West Africa, particularly in Mali, where providing health care for the poorest remains a big challenge. The majority of the region's countries are currently seeking to define the content of their compulsory, contribution-based medical insurance system. However, very few countries apart from Mali have decided to, in parallel, develop a solution for poorest that is not based on contributions.

Methods : This qualitative research article examines the historical process that has permitted the emergence of this ground-breaking public policy.

Results : The research shows that the process has been very long, chaotic and sometimes suspended for long periods. One of the biggest challenges has been that of intersectoriality and the social construction of the groups to be targeted by this public policy (the poorest), as institutional tensions have evolved in accordance with the political issues linked to social protection. Eventually, the medical assistance scheme for the poorest (RAMED) saw the light of day in 2011, funded entirely by the government.

Conclusions : RAMED emergence would appear to be attributable not so much to any new concern for the poorest in society but rather to a desire to give the social protection policy engaged in a guarantee of universality. The RAMED nonetheless remains an innovation within French-speaking West Africa.

\section{Introduction}

Academic texts addressing social protection policies in low-income countries remain a rarity, especially those concerning the most vulnerable groups such as the poorest or the elderly (Dupuis and Fagnani, 2018; Kadio, 2018). Recently, however, Africa has seen the development of numerous user fee exemption policies for children and pregnant women, who are classed as vulnerable groups in the field of social protection, and these policies have been very widely analysed with regard to both their emergence (agenda-setting) and their effects (Robert, Samb, et al., 2017). In an edited book from 2013, we sought to review the policies aimed at the poorest in Africa (Ridde and Jacob, 2013), and the observation made then regarding the lack of papers on the subject remains applicable, especially when the desire is to study public policies rather than one-off interventions or specific projects, which we know only rarely represent reality and are not suitable for scaling-up.

In Asia, the case of Cambodia is a remarkable one because its equity fund policy aimed at access to healthcare has been widely studied (Noirhomme and Thomé, 2006). The process of community-based targeting and its single social register which have resulted from these multiple experiments in the field of health were even made compulsory in 2011 for all social protection programmes aimed the country's poor. The emergence of this equity fund policy was the fruit of a strong political will and of intersectorial coordination by all of the stakeholders (national and international), in order to reduce the degree of fragmentation of the solutions implemented and to encourage a national consensus (Kaba et al., 2018). 
In Africa, these types of studies on emergence are much rarer (Berlan et al., 2014), especially as few countries have engaged in these social protection policies aimed at the poorest (Hickey et al., 2018). The coordinators of a recent special issue confirm that "the conditions for the emergence and development of social protection systems in Africa [are] still not well-known" (Dupuis and Fagnani, 2018). This is because, for a long time, the issue of poverty and of access to health care in particular has only rarely become a public issue which African and international decision-makers have chosen to address by organising sustainable solutions (Ridde, 2006). The international discourse calling for health coverage for the poorest, especially within the context of UHC (and its slogan: "Leaving no one behind"), still amounts to declarations of principle, despite their regular repetition for decades. The observation made during the 1990s (Kaddar et al., 2000; Stierle et al., 1999) of a rarity of mechanisms aimed at the poor remains valid today. We are still a long way from realising that access to care for the poorest in society is a fundamental human right within the context of UHC (Ooms, G et al., 2019; Robert, Lemoine, et al., 2017).

In North Africa, Morocco stands out as an exception courtesy of the generalised roll-out of its medical assistance system (RAMED) from 2012, after an experimental phase launched in 2008. The emergence of this policy results from a long process of maturation, trials, and draft laws which were at times forgotten before being resumed. However, the RAMED there fundamentally responds to the need to "ensure the stability of the political system - i.e. the protection of the monarchy's leadership within a determined process of liberalisation of authoritarianism" (Ferrié et al., 2018). The aim appears to be truly focused on the need to "re-legitimise the monarchy" (Ferrié and Omary, 2019).

In Sub-Saharan Africa, a handful of countries have embarked upon these public policies of social protection for the poorest. In Burkina Faso, recent research has shown how the national and international stakeholders have galvanised themselves and coalesced in order to develop such a social protection policy (Kadio, Dagenais and Valery Ridde, 2018). However, the formulation of its content can be classed more as a compilation of the pre-existing actions, against a background of aid dependency (Olivier de Sardan, 2014), rather than a genuine and coherent reflection of the interventions needing to be organised in order to meet the needs of the poorest (Kadio, Dagenais and Valéry Ridde, 2018). In Benin, the extensive process of targeting the poorest seen since 2013 has primarily resulted from the impetus of the World Bank, without any quota being explicitly set (Deville, Escot, et al., 2018). In Senegal, the state has, since the same year, been running a programme aimed at the poorest which not only grants them direct cash transfers but also allows them to become members of the community-based health insurance $(\mathrm{CBHI})$ schemes free of charge. The emergence of this programme was largely political, as it had been an electoral promise made by Macky Sall. As a result, the launch was rushed and chaotic, "ill-considered" and "without consultation" (Ferrié \& Omary, 2019). In Ghana, people classified as the poorest (also beneficiaries of a cash transfer programme, Livelihood Empowerment Against Poverty) are enrolled free of charge on the national health insurance scheme, on paper since 2004 but in reality since 2013 (Umeh, 2018). Political issues, a desire to make the system fairer and expert evidence originating from a similar programme in Brazil (Foli, 2016) are the main reasons behind the emergence of this policy, even if the decision appears to be more symbolic than based on any true commitment (Kotoh and Van der Geest, 2016; Seddoh and Akor, 2012). In Rwanda, the poorest also benefit from exemption from the payment of 
the health mutuals' subscriptions and there too, it was the ideology of the party in power after 1994 and the power balance with the Global Fund to Fight AIDS that resulted in the emergence of this policy and the funding of this subsidy for the poor from 2007 (Chemouni, 2018).

To our knowledge, Mali is the only country in French-speaking West Africa since 2011 to have put in place an ambitious self-funded national policy specifically designed to provide the poorest (it applies to $5 \%$ of the total population) with free medical cover. No research analysing its emergence has yet been published. The aim of this article is therefore to understand the process that has led Mali to proceed with the formulation of a social protection policy of this type.

\section{Background: Access To Care And The Ramed}

Since 1968, a decree has applied to the regulation of help for the poorest but it has never been applied. In the 1980s, Mali was one of the first countries to roll out a cost recovery scheme whereby health service users were asked to pay at the point of use (Maïga et al., 1999). The nation has since undergone multiple health reform processes, whether to improve the health system's governance and decentralisation, to train personnel or to enhance the quality of care. Faced with the challenge of financial accessibility, Mali put in place several user fee exemption policies from 2000 to 2010, primarily for caesareans, HIV-related care and anti-AIDS treatment for children. However, these policies were not as effective as had been hoped (Ravit et al., 2018) and the difficulties linked to implementation and funding remain considerable (Touré, 2015). Recourse to healthcare for the sick is still just as low and the most disadvantaged still experience major difficulties obtaining treatment in the formal sector given the numerous barriers they have to overcome, primarily financial ones.

Consequently, within the governmental context of the creation of compulsory medical insurance (AMO) to cover the risk of illness among civil servants and employees from the formal sector ( $17 \%$ of the population), the state arranged the set-up of a non-contribution-based system (the medical assistance scheme, or RAMED, formerly the medical assistance fund (FAM)), aimed at providing free medical care for the poorest ( $5 \%$ of the population). In order to cover the remaining $78 \%$ of the Malian population coming under the informal sector, the government decided to rely on the community-based health insurance (Deville, Hane, et al., 2018).

The RAMED is managed by the Agence Nationale d'Assistance Médicale (ANAM), a public administrative body with legal personality and financial autonomy. On its foundation in 2009, the ANAM, which is responsible for the registration of beneficiaries, was placed under the supervision of the Minister for Community Development and Humanitarian Action (MSAH). The RAMED is a scheme aimed at the poorest (indigents), namely "any person deprived of resources and recognised as such by the local authority covering them", to quote Act $09-030$ of 27 July 2009. The care package offered is equivalent to that received by beneficiaries of the AMO, excluding the cost of speciality medicines. In contrast to the other forms of user fees exemptions, which are largely funded through international aid (Ridde, 2015), the RAMED is financed exclusively via public funds, with the state providing $65 \%$. It was originally envisaged 
that the remaining 35\% would come from the local authorities but this provision, which was in many cases neither accepted nor applied, was revised in May 2017 and the share payable by the local councils cut to $15 \%$.

Having described the problem and given an overview of the background, we will now present the methods which we used to understand its emergence over the long term via the analysis of policy, as proposed by Sabatier and Weible (2014).

\section{Methodology}

This involved qualitative research conducted in the form of a holistic case study (Yin, 2009), the case concerned being the RAMED. Without falling into the stagism of the analysis of public policies (Sabatier and Weible, 2014), we were interested in its emergence, or in other words the agenda-setting (Hassenteufel, 2010; Kingdon, 1995). The empirical data results from two complementary methods.

Firstly, 11 qualitative and in-depth individual interviews were conducted from January 2017 to March 2018 in Bamako, the capital of Mali, using a qualitative sampling strategy (Palinkas et al., 2013) based upon the criteria of knowledge of and involvement in the emergence of the RAMED and, by way of a snowball effect, by following the recommendations of our initial interviewees. Thus, we met with the main persons to have played a central role in the emergence of this policy and representing all of the institutions involved, namely the health ministry $(n=1)$, the ministry for community development and humanitarian action $(n=9)$, and the Union Technique de la Mutualité $(n=1)$. The interviews were conducted in French by LT. They were all recorded and transcribed in full in order to facilitate their analysis.

Secondly, the empirical data also stemmed from numerous $(N=29)$ documents relating to social protection in general and to the RAMED in particular. Serving to facilitate understanding of the historical development of the process and the different stakeholders involved, these consisted mainly of public policy documents, legislative documents and articles and studies on the subject or on social and health policy from the period concerned.

A qualitative analysis of the content (Paillé and Mucchielli, 2003) of the data resulting from these two collection tools was also conducted, while triangulation processes between this data and the discussions on the preliminary analyses with the parties concerned helped to improve the research's internal validity. The results were primarily presented during two deliberative workshops held in Bamako in the presence of various stakeholders concerned by the analysis (in June 2018 with 16 participants and in February 2019 with 33 participants). Policy briefs (http://www.miselimali.org/\#Productions_scientifiques.D) also helped to facilitate the discussions with the stakeholders regarding our analyses.

The research benefited from the authorisation of the INRSP's ethics committee (No.24/2015/CE-INRSP) and a partnership agreement signed between the research team and the ANAM in order to increase cooperation with a view to knowledge transfer. 


\section{Results And Discussion}

\section{A long, political and chaotic process of emergence}

The history of the RAMED's emergence stretches over a period of almost 20 years, between 1991 and 2009 , the year in which the legislative texts were finally adopted. This lengthy duration underlines the importance of the historical authenticity of public policies and the temporality of analyses (Laborier and Trom, 2003). The process was discontinuous, consisting of successive periods of intense activities or of interruption, somewhat like the theoretical proposals of True, Jones \& Baumgartner (2007). This history was punctuated by four main periods.

\section{1 to 1997: a degree of political will}

Alpha Oumar Konaré, the first President to be democratically elected following the 1991 coup d'état that put an end to 23 years of military dictatorship, was sympathetic regarding social issues. In 1980, while a civil servant in the national education department, he had been the instigator of Mali's first health mutual, the MUTEC. In 1992, the President expressed the desire to separate the department of social affairs from the health ministry and to bring it under the control of local government ministry. However, this initiative was not regarded favourably and the trade union for personnel from the health and social action sectors arranged marches to oppose it, leading to the project's abandonment. Following a study tour to Tunisia in order to observe the social protection system, the President then expressed the desire to develop social protection in Mali. This resulted in the 1993 declaration of a community development policy. As for Ghana's social protection programme where those in charge travelled to Brazil (Foli, 2016), it amounted to a new demonstration of the role of study tours* in the public policies transfer in Africa, especially in Mali (Gautier et al., 2019).

This period was characterised by a high level of planning activity. In the area of health, this took the form of institutional reforms (Maïga et al., 1999) and the creation of a health development plan (PDS) 19982007, which for the first time made reference to eventual guaranteed UHC through the mutuals (for the liberal professions and the self-employed), compulsory medical assistance (for employees and civil servants) and a medical assistance fund for persons not covered by any other insurance scheme and recognised as indigent.

The technical and financial partners (PTF) provided support throughout the PDS's planning phase, but they began to focus more on the reinforcement of the offer via the implementation of the ambitious sectoral decentralisation plan in the field of health, displaying a marked disinterest in the social issues. The Malian government was thus forced to impose inclusion of the social sector in the shape of the Programme de Développement Sanitaire et Social (PRODESS 1998-2002).

"The partners regarded social affairs as an extension to health. Even the World Bank did not at the time want social action to be included in the PRODESS. Its representatives would say that it was not possible to take taxes from people to come and assist the poorest in Mali when they had their own 
poor. That was the idea they put in the partners' heads and it took all the energy of Modibo Sidibé at the Ministry of Health to get social action included": a former executive at the community development ministry.

This highlights the importance of the appropriation of public policies by African governments and leaders and the weight of the ideas and funding from international partners in the field of health (Gautier and Ridde, 2017; Kuhlmann et al., 2019) and social protection (Foli, 2016). In the case in point, and contrary to the norm, the national party was in a position to be able to stand strong so that its ideas on the role of the social sector could prevail.

An ad hoc group, set up within the framework of the development of a ten-year plan and placed directly under the responsibility of the Prime Minister, was tasked with development of a social protection policy.

"Against a background of structural adjustment, the foreign experts, galvanised for the development of the ten-year plan, brought forward the idea of planning a third strand to the PRODESS entitled "alternative health funding methods with AMO, FAM and mutuals"': a DNDS manager.

Technical capacity for the management of sickness insurance in Mali was then practically non-existent (Letourmy and Ouattara, 2006). In 1997, the ad hoc group commissioned a feasibility study which presented an institutional set-up of the different schemes envisaged (AMO and FAM) and an estimation of the technical costs and the contributions according to different healthcare baskets. On this basis, the ad hoc group put forward a draft law that established a social protection code, but this was never adopted by the government or submitted to a vote due to fears of the financial consequences for the state. The only real achievement was the production in 1996 of a legislative and regulatory system governing the mutuals. The Union Technique de la Mutualité(UTM) was then created in 1998, with French and Belgian assistance at a technical level.

With regard to the poorest, the results generated during this period were decidedly mediocre. The political will of the government to establish a genuine community development policy resulted in the first ever entry in the state budget of a funding line devoted to actions and programmes for community development, at a level of 43 million CFA francs in 1992 and up to 110 million in 1997 (Sidibe, 2017). According to a national policy document, "the national hospitals' social services received, from 92 to 96 , $7,280,000$ FCFA for care in urgent cases and those involving patients without resources (the poorest)" (Sidibe, 2017), although the exact distribution in favour of the poorest is not known.

\section{From 1998 to 1999: the first phase of interruption}

It was during this period that a first interruption occurred in the social protection policy's process of emergence. The ten-year plan of which it formed a part was the subject of lengthy consultation, which delayed the progression of the work (Sidibe, 2017). Moreover, this plan needed to be rolled out in two fiveyear programmes (PRODESS), the finalisation of which was delayed. The implementation of the PRODESS's institutional architecture proved to be a major struggle. 
"There was a lack of proactivity regarding the set-up of the PRODESS's different bodies, i.e. the regional orientation committees, the technical committees involving the different ministries and the departments, and the monitoring committee that was chaired by the ministers themselves. All of these bodies needed to be set up but that didn't happen until 1999 and 2000. And then the funds were not entirely available because there were several partners involved and multilateral aid to be coordinated. All of this meant that it wasn't until 2000 that the matter was able to be resolved, after quite a bit of delay": a former executive from the MDSSSPA Ministry.

Lastly, the reformist trend generated some concerns. The presidential vision of social protection struck some as avant-gardist. Doubts regarding both the state's will and technical capacity to put in place such systems for the benefit of the population were clearly expressed. Against a newly democratic background, the imposition by the state of a system that was compulsory for some (civil servants from the AMO) and non-contribution-based for others (the poorest from the FAM) seemed anachronistic and provoked some resistance.

"In the end, only the community-based health insurance (mutual) aspect was developed. The AMO and the medical assistance fund, meanwhile, had to be halted and time out taken, because people didn't understand that the aim was to introduce compulsory sickness insurance. The group's ad hoc work had begun in 1996, just five years on from the 1991 revolution, which led to a coup d'état and democracy being introduced. In fact the people had begun to feel free and this promise of freedom did not fit in well with any concept of obligation. So people were saying to each other than nothing should be compulsory any more": a former MSSPA ministry executive.

The role of these ideas in the construction, emergence and transfer of public policies (Béland and Cox, 2011; Kuhlmann et al., 2019) was also confirmed in this West African country's social policies (Béland and Ridde, 2016). The issue of the compulsory nature of membership of the CBHI and the state's role of stewardship of the health system had been central to the emergence of the UHC in Rwanda (Chemouni, 2018; Habiyonizeye, 2013), in contrast to in Mali or Senegal (Ridde et al., 2018). Indeed, a 2016 study conducted in Mali demonstrated that it was "the obligation that had been the decisive factor in the rejection of social insurance." (Goita, 2018).

The anticipated institutional upheaval in the health field also caused concerns, particularly the administrative and sectoral decentralisation that would grant certain powers to community stakeholders and to elected representatives.

\section{From 2000 to 2005: intensive discussion and study activities against a background of doubts}

In 2000, the government achieved a major institutional reform: the creation of a ministry for social and community development and the elderly (MDSSPA). Its aim was to develop a whole new conception of the social sector. 
"The new body believed that the old forms of social protection, of which the effectiveness and human quality remained undeniable, could not cover the entire field. It wanted to encourage a social protection policy which resulted from straightforward assistance and involved those concerned and the population as a whole." (Sidibe, 2017).

Two strong initiatives underline this new ministry's desire to bring about emancipation, which was hampered by a lack of human, technical and financial resources:

- the research by International Labour Organization (ILO) technical assistance, which funded the conducting of three studies on the analysis of the social protection system. This support was important against a background of lack of national expertise in this new field.

- the set-up of a social protection orientation council (COPS) by the MDSSPA.

2001 saw the holding of the first social development sittings to give content to this new ministry's policy.

"On this occasion, we resumed all of the old plans concerning social action and that were lodged with the Ministry of Health. And we requested the reintroduction of the AMO and the Medical Assistance Fund": a former MSSPA executive.

"It was at that point that the idea was revived of having guaranteed medical cover via a social security scheme. But it wasn't clear what instrument should be used, which is why we called upon a French expert for a preliminary evaluation of what could be set up in Mali as a mechanism to help alleviate medical insecurity. It was XX who came to carry out this study": a former MDSSPA executive.

This national event marked an important turning point in the field of social development. It remains associated with the international window of opportunity (Kingdon, 1995) opened up by the targets of the Millennium Development Goals of September 2000. Three main orientations were adopted by the government as a result of the work conducted at these first sittings: the consolidation of national solidarity and the reinforcement of the struggle against exclusion, the strengthening of social protection and the fight against poverty.

In order to ensure the reliability of the community system deployed in the field of health, interest in social protection clearly increased, as it had in the 1990s, i.e. underlining the dependence on the political instrument route (Sabatier and Weible, 2014) and centred on effectiveness, in terms of asking how the poorest could be taken care of (Maïga et al., 1999; Stierle et al., 1999).

"With the new policy, the CSCOM had to rely on the revenue (user fees) streams generated by these services. All of the studies conducted had yielded positive results, except for those on the issue of poverty. The poorest couldn't pay. You know that the CSCOM provides medicines at low prices and that the ASACO is an association. The association's members pay contributions that go towards its functioning, but how can those without the means to pay be included? Free of charge. And it was 
clear that if free membership was introduced, the CSCOM would not survive. So it was necessary to find a solution for them. Poverty constituted a burden that was preventing the correct set-up and development of the ASACOs. In order to avoid excluding the poorest, at the first PRODESS, it was concluded that the alternative system needed to consist of two strands: the CBHI for those able to contribute and, secondly, for the system to remain viable, we need to cover the issue of poverty": a DNDS executive.

In 2002, the declaration of a policy for the extension of social protection was adopted by the Council of Ministers. It would be followed in November 2004 by a national action plan for the extension of social protection in Mali (2005 - 2009).

In 2005, two national experts were appointed for the synthesis of the work conducted and the proposal of an institutional organisation plan for the AMO and the FAM. On the basis of their conclusions, complementary studies were requested, "one concerning the institutional set-up proposed and drawing the consequences of this in terms of cost and investment, and the other, technical in nature, relating to the parameters and quantitative elements of the systems proposed both for the AMO and for the FAM" (Letourmy and Ouattara, 2006). A second feasibility study put forward different scenarios relating to the system's institutional organisation and the updating of the data followed by a national consultation regarding its conclusions (Letourmy and Diakité, 2003).

One striking aspect revealed by the historical analysis of social protection in Mali is the repeated use of the same experts. It was surprising to observe the lack of diversity in the expertise deployed to offer advice to the government. Most of the reports were written by the same experts, who are usually from France or trained in France. This shows how much the role of the technical entrepreneurs of spreading ideas is central in this context (Gautier et al., 2019), as well as the role of consultants in public policy in West Africa (Olivier de Sardan, 2011).

Concerning the FAM, which would later become the RAMED, we did not find any mention of analytical studies on the context, existing systems or current practices regarding the coverage of the poorest by the health structures, and their limitations. To our knowledge, a single local experiment with a medical assistance fund project has been conducted by MSF-Luxembourg (MSF-L), successively at two district hospitals (CSREF) in the region of Sikasso, Sélingué in 2001 and at Bougouni in 2003, based on the equity fund experimented with in Cambodia (Noirhomme and Thomé, 2006; Ridde, 2012). The FAM's operation was funded by the municipalities (25\%), the district hospital (CSREF) (25\%) and MSF-L (50\%). However, after three years of operation, the FAM in Sélingué had supported just $2 \%$ of hospitalised patients, of which only $9 \%$ were recognised as poorest and entitled to full user fee exemption (Noirhomme and Thomé, 2006). This absence of investment in pilot projects is surprising but perhaps demonstrates the low degree of importance granted to this issue. In fact, this region of Africa, including Mali, has seen a very large number of experiments concerning user fees for healthcare within a context of decentralisation (Ridde, 2015), but very few regarding healthcare access for the poorest. It was only in 2019 that Senegal organised a pilot project in one district for the integration of its free healthcare policies within its national 
health insurance system (Daff et al., 2019). Conversely, when the situation in South-East Asia is examined, it is clear how many of these pilot projects have been instrumental in the emergence of social protection policies in favour of the most deprived (Asante et al., 2019).

However, the Malian state has struggled to establish its credibility with regard to its declared aims, with numerous doubts arising in relation to its ability to equip the country with such systems: poor nation, problems of governance, health system deficient or corrupt, etc.

"Another issue was that the people didn't believe in social protection. I'll tell you an anecdote that might aid your understanding a little. At the time, i.e. 2004 or 2005, at a PRODESS monitoring committee meeting chaired by the Minister, the national health director raised his hand. He said that during the night we can have dreams, that's normal, but when these dreams are unachievable, you keep them to yourself. There's no need to share them with others. He was in fact referring to the AMO and to the FAM, saying that they were just dreams. And that was the national health director!": an MSAH executive.

However, several user fee exemption policies (HIV in 2004, caesarean in 2005, anti-malaria for children and pregnant women in late 2006) have been put in place, decisions which were highly political and technically contested in their formulation (Touré, 2015). Championed by the Health Ministry and widely supported internationally (Robert, Samb, et al., 2017), these initiatives occupied the forefront of the political scene and attracted widespread attention, eclipsing the development of the social protection system and health cover for the poor.

The background was that of a social sector which was struggling to separate itself from the field of health in order to reinvent itself around more ambitious policies. This longstanding control of social protection by health, initially institutional up until 2000 (a single minister for both sectors), then financial within the framework of the PRODESS funding, and finally symbolic (health professionals considered themselves alone to be the authorities on all matters linked to health) served to maintain a somewhat wait-and-see approach on the part of social contributors, who were also faced with a chronic deficit in terms of human resources. The funding from which the new ministry benefited was the subject of bitter debate within the health sector, as it included no support from partners and was always well below that required to fulfil its declared aims.

"15\% of the PRODESS budget was allocated to social protection. And even getting to that $15 \%$ level required negotiations with ministers because at the start, we only got $5 \%$. That was around 2006,1 think. The World Bank at the time placed us at a disadvantage by saying that it only wanted a single contact. And when there were two ministers, the World Bank said that its sole contact would still be the Health Minister": a former MDSSPA executive.

"Another element of blockage was the fact that there were no available partners, due to a lack of belief": an MSAH executive. 
This analysis shows once again the crucial role played by international aid organisations in the emergence of policies in Africa and the challenges involved in obtaining their support (Gautier and Ridde, 2017).

Eventually, this new Ministry for Social and Community Development and the Elderly, which was responsible for guiding and uniting the stakeholders around a process for the development of a social protection system, had to build itself up and equip itself with new skills in terms of social insurance.

At the same time, it was forced to impose its leadership on the other ministries involved, which were not always interested or cooperative, such as the Health Ministry, which had the supervision of this health insurance project taken away from it. Since Alma-Ata in 1978 up until the present day and UHC, this issue of intersectoriality keeps on cropping up and is central to the current construction of public policies in Africa (Blas et al., 2016; Soors et al., 2013).

\section{6 to 2009: the system's slow maturation and institutional tensions}

At the time, UHC was not an international priority and the partners had few solutions to offer to ensure support for the AMO (Noirhomme and Thomé, 2006) and the RAMED. This period was characterised by the project's slow advancement, small steps, lack of skills in the social sector, and fear of the reactions that these social reforms might generate. Moreover, despite the new President (elected in 2002) Amadou Toumani Touré (ATT) displaying a stronger desire than ever to obtain a national consensus, progress was decidedly sluggish.

The formulation of these policies and that of the AMO in particular accentuated tensions and opposition to the project and highlighted the weak contribution from other sectors: "The perseverance of the Malian authorities vis-à-vis the AMO project suggested that there was political will but the duration of the process made one think that this wasn't sufficient to resolve the institutional tensions that emerged or to arbitrate between contradictory positions" (Letourmy and Ouattara, 2006). The intersectoriality remained very difficult to implement (Blas et al., 2016) and the famous advocacy coalitions (Sabatier and Weible, 2014) were not working towards the consideration of equality in this context. The extremely lengthy duration of the process and discussions, along with solutions of which the stability worked against the necessary changes for greater fairness, recalled the theoretical proposals of Hall (1993) and the paradigms of public policy. Hall (1993) clearly showed, however, just how important it was to take into account tensions between "puzzling" and "powering" and, in the present case, the asymmetry of powers between the network of stakeholders, particularly between international and national ones. The consideration of the role of the ideas of the stakeholders in Mali active in maintaining the relative stability of social protection policies became essential (Daigneault, 2014).

Locally, the health care providers regarded this initiative, which affected them in more ways than one, as a dual threat: 
- as civil servants, they were likely to be members of the AMO and feared losing the benefits they had acquired compared to the other bodies,

- as health professionals, since the deployment of these social protection systems would need to be accompanied by service control mechanisms, would favour generic medicines over specialist ones, and would not take into account the private sector in which they had special interests (Letourmy and Ouattara, 2006).

However, a slow but positive process of change can be observed in the health sector in favour of social protection systems. This paradigm shift is subtle (Daigneault, 2014) and analysis of these policies clearly needs to be conducted over a longer term (Sabatier and Weible, 2014). From total disinterest towards this "utopia" at the start, social protection has become established as an alternative to payment exemption policies. Imposed without any consultation by the country's highest authorities, the latter are in fact particularly poorly received by health professionals and even considered harmful to the viability of the health structures and the personal interests of professionals. Furthermore, the health professionals believe that the structuring of these policies in relation to social protection mechanisms has not been sufficiently considered or planned in advance by those responsible (Touré, 2013, 2015). The AMO therefore appears to be the least bad option for health professionals, provided that it is possible for its implementation conditions to be negotiated.

The social partners (trade unions in particular, see case of higher education staff (Goita, 2018)) have adopted a fairly ambivalent position regarding the set-up of the AMO. Mali's two major unions officially support the principle but fear the levelling of situations between civil servants that the AMO implies. Furthermore, in perpetual competition and on a quest for visibility and power, the consequences of which for public policies are well-known (Béland, 2010; Hall, 1993), they generally adopt opposing positions regardless of the subject under discussion and irrespective of the consequences.

"The head of the Workers' Trade Union Confederation of Mali (CSTM) was against it and so all the unions linked to his confederation rejected the AMO. The UNTM, the other main trade union, was for the AMO and all the unions affiliated to it followed his line. Up until today, when the UNTM takes one direction, the CSTM takes the opposite one. These are conflicts that predate the issue of the AMO and are more or less attributable to political or union-related matters or opposition between individuals. One thing's for sure though: they never agree": a former MDSSPA executive.

Concerning the RAMED in particular, there have been fewer issues and fewer conflicts between those involved. The comparison with the history of the AMO is therefore heuristic. The FAM became the RAMED at the meeting of the general secretaries of the different ministries for the adoption of the text. Basically, they took the view that it amounted to a scheme, even though it is not contribution-based, and that it was therefore necessary to change its name. Apart from this issue, which to an extent smacks of the social construction of the targets of public policies (Schneider and Ingram, 2005), the RAMED appears very simple to implement compared to the AMO, which required construction ex nihilo, and its set-up generated very little debate. 
"The discussions on the RAMED were concluded more rapidly. The targets were known and accepted and the contributions were calculated. And it was settled. But on the AMO side, there was much more debate, as it provoked more opinions than the RAMED": a former MDSSPA executive.

"Generally speaking, the RAMED has posed fewer problems than the AMO. There was almost no debate at all on the RAMED and people were unanimous about the benefits of going ahead with it. All of civil society was for it. The associations for disabled people even wanted their members to all be directly included. It was explained to them that this wasn't compatible with what they were seeking, namely more equality of opportunity. They wanted to be included in the same way as able-bodied persons, but if you let yourself be marginalised like the destitute and the poor, well that just doesn't work": a former MDSSPA executive.

In the end it was a version of the system that was both vague and unrenewed that evolved up until the formulation of the legislative texts submitted to the National Assembly. Laws and decrees concerning the creation of the ANAM and the CANAM (Mali's national health insurance fund), and of the AMO and the RAMED, were adopted in July 2009. The adoption of these texts did not of course indicate the finalisation of the formulation of these policies. Those responsible were aware that the texts needed to be clarified and considered that the discussion work needed to improve the formulation of the systems was now the responsibility of the teams recruited, both at the CANAM and the ANAM.

*This type of strategy is so important that certain international organisations such as the International Labour Office (ILO) and the World Bank have produced guides for organising such study tours (Kumar and Watkins, 2017; Steinmann, 2010).

\section{Conclusion}

The analysis of the emergence of this ambitious policy in favour of Mali's poorest citizens demonstrates the importance of the role of the policy entrepreneurs when it comes to breaking away from processes which are secular in terms of sector. This is made all the more remarkable by the fact that access to healthcare for the poorest has not been a priority, either for the national authorities or for the international partners. But this attempted break with tradition has occurred over a lengthy time span and against the background of a battle between sectors, most notably between health and social protection. It is almost as if the issue of poverty and its inclusion in social protection policies is a foil to the principle of universality, which has struggled to find a place within a system that especially benefits the poorest. The complexity and low effectiveness of the $\mathrm{CBHI}$ have restricted the decision-makers in Mali in their development of UHC for the two extremes of the social continuum, i.e. the very poor on the one hand, and the less poor on the other. However, this emergence of a policy in favour of the poorest is not for the moment synonymous with genuine consideration for the most deprived. The analysis of the formulation and then the study of its actual practical application would certainly show us all the importance (or not) that those in charge give to their fellow citizens living in poverty. The fact that the Malian government has 
just decided (in June 2019) that social protection will once again be integrated within the Health Ministry to the detriment of the Social Action Ministry does not augur well in this regard.

\section{Declarations}

\section{ETHICS APPROVAL AND CONSENT TO PARTICIPATE}

The research protocol has been validated by the ethics committee of the National Institute of Public Health Research (INRSP) of Mali ( $\left.{ }^{\circ} 24 / 2015 / C E-I N R S P\right)$. Participants provided consent to participate, as required by the ethics committees.

\section{CONSENT FOR PUBLICATION}

Not applicable

\section{AVAILABILITY OF DATA AND MATERIAL}

The data generated and analyzed during the current study are not publicly available to protect confidentiality of participants. They may be available from the corresponding author on reasonable request if the ethical guidelines of both committees involved can be respected.

\section{COMPETING INTERESTS}

The authors have no conflict of interests regarding the publication of this paper.

\section{FUNDING}

This work has been supported by International Development Research Centre (IDRC).

\section{AUTHORS' CONTRIBUTIONS}

LT and VR conceived the study protocol. LT collected and analyzed the data with VR support. Both authors wrote the first draft of the manuscript, read and approved the final version.

\section{ACKNOWLEDGEMENTS}

The authors express their gratitude to all participants for their generous contributions to this study.

\section{References}

Asante AD, Jacobs B and Wiseman V (2019) Transforming health systems financing in Lower Mekong: making sure the poor are not left behind. Health Policy and Planning 34(Supplement_1): i1-i3. DOI: 10.1093/heapol/czz098. 
Béland D (2010) The Idea of Power and the Role of Ideas. Political Studies Review 8(2): 145-154. DOI: 10.1111/j.1478-9302.2009.00199.x.

Béland D and Cox RH (eds) (2011) Ideas and Politics in Social Science Research. New York: Oxford University Press.

Béland D and Ridde V (2016) Ideas and Policy Implementation: Understanding the Resistance against Free Health Care in Africa. Global Health Governance 10(3): 9-23.

Berlan D, Buse K, Shiffman J, et al. (2014) The bit in the middle: a synthesis of global health literature on policy formulation and adoption. Health Policy and Planning 29(suppl 3): iii23-iii34. DOI:

10.1093/heapol/czu060.

Blas E, Roebbel N, Rajan D, et al. (2016) Intersectoral planning for health and health equity. In: Schmets G, Rajan D, Kadandale S, et al. (eds) Strategizing National Health in the 21st Century: A Handbook. Geneva, Switzerland: World Health Organization.

Chemouni B (2018) The political path to universal health coverage: Power, ideas and community-based health insurance in Rwanda. World Development 106: 87-98. DOI: 10.1016/j.worlddev.2018.01.023.

Daff BM, Diouf S, Diop ESM, et al. (2019) Reforms for financial protection schemes towards universal health coverage, Senegal. Bulletin World Health Organization Article ID: BLT.19.239665(In Press).

Daigneault P-M (2014) Reassessing the concept of policy paradigm: aligning ontology and methodology in policy studies. Journal of European Public Policy 21(3): 453-469. DOI:

10.1080/13501763.2013.834071.

Deville C, Hane F, Ridde V, et al. (2018) La Couverture universelle en santé au Sahel: la situation au Mali et au Sénégal en 2018. Working Papers du CEPED (40). Paris.

Deville C, Escot F, Ridde V, et al. (2018) Les processus d'identification des plus pauvres à l'épreuve du terrain: une comparaison Bénin-Mali-Sénégal. In: Production et diffusion de mécanismes miracles dans I'industrie du développement, Roskilde University, Denmark, 2018. Available at: http://hdl.handle.net/2268/226060.

Dupuis J-P and Fagnani J (2018) Avant-propos. Revue française des affaires sociales (1): 5-12.

Ferrié J-N and Omary Z (2019) La trappe des décisions irréfléchies: le Régime d'assistance médicale au Maroc (RAMed) et le Plan Sésame au Sénégal. Mondes en développement 47(187): 15-28.

Ferrié J-N, Omary Z and Serhan O (2018) Le Régime d'assistance médicale (RAMed) au Maroc : les mécomptes du volontarisme et de l'opportunisme. Revue française des affaires sociales (1): 125-143. 
Foli R (2016) Transnational actors and policymaking in Ghana: The case of the Livelihood Empowerment Against Poverty. Global Social Policy: An Interdisciplinary Journal of Public Policy and Social Development 16(3): 268-286. DOI: 10.1177/1468018115615643.

Gautier L and Ridde V (2017) Health financing policies in Sub-Saharan Africa: government ownership or donors' influence? A scoping review of policymaking processes. Global Health Research and Policy.

Gautier L, Coulibaly A, De Allegri M, et al. (2019) From Amsterdam to Bamako: a qualitative case study on diffusion entrepreneurs' contribution to performance-based financing propagation in Mali. Health Policy and Planning: czz087. DOI: 10.1093/heapol/czz087.

Goita SO (2018) Les difficultés de mise en place de l'assurance maladie obligatoire au Mali : le cas des enseignants du supérieur. Revue française des affaires sociales (1): 199-204.

Habiyonizeye Y (2013) Implementing Community-Based Health Insurance schemes. Lessons from the case of Rwanda. Master Degree in International Social Welfare and Health Policy. Oslo and Akershus University College of Applied Sciences, Faculty of Social Sciences. Available at:

https://oda.hioa.no/nb/implementing-community-based-health-insurance-schemes-lessons-from-thecase-of-rwanda/asset/dspace:5437/Habiyonizeye_Yvonne.pdf.

Hall P (1993) Policy paradigms, social learning and the state: the case of economic Policymaking in Britain. Comparative Politics 25(3): 275-96.

Hassenteufel P (2010) Les processus de mise sur agenda: sélection et construction des problèmes publics. Informations sociales 157(1): 50-58.

Hickey S, Lavers T, Niño-Zarazúa M, et al. (2018) The Negotiated Politics Of Social Protection In SubSaharan Africa. Helsinki: WIDER Working Paper 2018/34 : UNU-WIDER.

Kaba MW, Baesel K, Poch B, et al. (2018) IDPoor: a poverty identification programme that enables collaboration across sectors for maternal and child health in Cambodia. BMJ 363. DOI:

10.1136/bmj.k4698.

Kaddar M, Stierle F, Schmidt-Ehry B, et al. (2000) L'accès des indigents aux soins de santé en Afrique subsaharienne. Tiers-Monde 41(164): 903-925. DOI: 10.3406/tiers.2000.1444.

Kadio K (2018) Politique publique de protection sociale au Burkina Faso: vers une compréhension des logiques des acteurs de la mise en forme et de la mise en œuvre. Thèse de doctorat en sciences humaines appliquées. Université de Montréal, Montréal (Québec, Canada).

Kadio K, Dagenais C and Ridde Valéry (2018) De la formulation d'une politique nationale à la compilation d'actions de protection sociale: un cas de «non-design » au Burkina Faso. International Development Policy / Revue internationale de politique de développement. 
Kadio K, Dagenais C and Ridde Valery (2018) Politique nationale de protection sociale du Burkina Faso : contexte d'émergence et stratégies des acteurs. Revue française des affaires sociales (1): 63-84.

Kingdon JW (1995) Agendas, Alternatives and Publics Policies. 2nd ed. New York: Harper Collins.

Kotoh AM and Van der Geest S (2016) Why are the poor less covered in Ghana's national health insurance? A critical analysis of policy and practice. International Journal for Equity in Health 15(1): 34. DOI: 10.1186/s12939-016-0320-1.

Kuhlmann J, González de Reufels D, Schlichte K, et al. (2019) How social policy travels: A refined model of diffusion. Global Social Policy. 146801811988844. DOI: 10.1177/1468018119888443.

Kumar S and Watkins R (2017) The art of designing and implementing study tours: a guide based on the art of knowledge exchange methodology. Working Paper: 119847. Washington, D.C.: World Bank Group.

Laborier P and Trom D (eds) (2003) Historicités de l'action publique. Publications du Centre Universitaire de Recherches Administratives et Politiques de Picardie. Paris: Presses Univ. de France.

Letourmy A and Diakité BD (2003) Etude pour la mise en place de l'assurance maladie bligatoire et du fonds d'assistance médicale. April. Bamako: Ministère du développement social, de la solidarité et des personnes âgées.

Letourmy Alain and Ouattara $O$ (2006) L'assurance médicale obligatoire au Mali : discussion d'un processus en cours. In: Dussault G, Fournier P, and Letourmy A. (eds) L'assurance Maladie En Afrique Francophone: Améliorer l'accès Aux Soins et Lutter Contre La Pauvreté. Washington: Banque Mondiale, pp. 229-262.

Maïga Z, Traoré Nafo F and El Abassi A (1999) La Réforme Du Secteur Santé Au Mali 1989-1996. Studies in health services organisation \& policy 12. Antwerp, Belgium: ITG Press.

Noirhomme M and Thomé J-M (2006) Les fonds d'équité, une stratégie pour améliorer l'accès aux soins des plus pauvres en Afrique? In: Dussault G, Fournier P, and Letourmy A (eds) L'Assurance Maladie En Afrique Francophone: Améliorer l'accès Aux Soins et Lutter Contre La Pauvreté. Washington: Banque mondiale, pp. 431-454.

Olivier de Sardan J-P (2011) Promouvoir la recherche face à la consultance. Autour de l'expérience du Lasdel (Niger-Bénin). Cahiers d'études africaines 202-203(2-3): 511-528.

Olivier de Sardan J-P (2014) La manne, les normes et les soupçons: Les contradictions de l'aide vue d'en bas. Revue Tiers Monde 3(3): 197. DOI: 10.3917/rtm.219.0197.

Ooms, G, Keygnaert, I. and Hammonds, R (2019) The right to health: from citizen's right to human right (and back). Public health 172: 99-104. 
Paillé P and Mucchielli A (2003) L'analyse Qualitative En Sciences Humaines et Sociales. Paris: Colin.

Palinkas LA, Horwitz SM, Green CA, et al. (2013) Purposeful Sampling for Qualitative Data Collection and Analysis in Mixed Method Implementation Research. Administration and Policy in Mental Health and Mental Health Services Research. DOI: 10.1007/s10488-013-0528-y.

Ravit M, Audibert M, Ridde V, et al. (2018) Do free caesarean section policies increase inequalities in Benin and Mali? International Journal for Equity in Health 17(1). DOI: 10.1186/s12939-018-0789-x.

Ridde V (2006) L'accès des indigents aux services de santé au Burkina Faso: un problème public? Lien social et Politiques 55: 149-163.

Ridde V (2012) Les fonds d'équité pour améliorer l'accès aux soins des plus pauvres. In: L'accès aux soins de santé en Afrique de l'Ouest: Au-delà des idéologies et des idées reçues. Presses de l'Université de Montréal, pp. 235-248. DOI: 10.4000/books.pum.8686.

Ridde V (2015) From institutionalization of user fees to their abolition in West Africa: a story of pilot projects and public policies. BMC Health Services Research 15(3): 1-11. DOI: 10.1186/1472-6963-15-S3S6.

Ridde V and Jacob JP (2013) Les Indigents et Les Politiques de Santé En Afrique. Expériences et Enjeux Conceptuels. Louvain-La-Neuve: Academia-L'Harmattan.

Ridde V, Asomaning Antwi A, Boidin B, et al. (2018) Time to abandon amateurism and volunteerism: addressing tensions between the Alma-Ata principle of community participation and the effectiveness of community-based health insurance in Africa. BMJ Global Health 3(Suppl 3): e001056. DOI: 10.1136/bmjgh-2018-001056.

Robert E, Samb OM, Marchal B, et al. (2017) Building a middle-range theory of free public healthcare seeking in sub-Saharan Africa: a realist review. Health Policy and Planning 32(7): 1002-1014. DOI: 10.1093/heapol/czx035.

Robert E, Lemoine A and Ridde V (2017) Que cache le consensus des acteurs de la santé mondiale au sujet de la couverture sanitaire universelle? Une analyse fondée sur l'approche par les droits. Canadian Journal of Development Studies / Revue canadienne d'études du développement 38(2): 199-215. DOI: 10.1080/02255189.2017.1301250.

Sabatier PA and Weible CM (eds) (2014) Theories of the Policy Process. Third edition. Boulder, CO: Westview Press, a member of the Persus Books Group.

Schneider AL and Ingram H (eds) (2005) Deserving and Entitled. Social Constructions and Public Policy. Albany: State University of New York Press. 
Seddoh A and Akor SA (2012) Policy initiation and political levers in health policy: lessons from Ghana's health insurance. BMC Public Health 12(Suppl 1): S10.

Sidibe M (ed.) (2017) La Politique Sanitaire et Sociale Au Mali 1992-1996. Les Choix, Les Actions et Les Perspectives. Bamako: Edition Jamana.

Soors W, Dkhimi F and Criel B (2013) Lack of access to health care for African indigents: a social exclusion perspective. International Journal for Equity in Health 12(1): 91. DOI: 10.1186/1475-9276-1291.

Steinmann R (2010) Exchange Visit Guide for Microinsurance Practitioners. Geneva: International Labour Organization.

Stierle F, Kaddar M, Tchicaya A, et al. (1999) Indigence and access to health care in sub-saharan Africa. International journal of health planning and management 14: 81-105.

Touré $L$ (2013) Perceptions of healthcare fee exemption policies in Mali: Is a decline in quality the price to be paid for improved access to care? In: Ridde V and Olivier de Sardan J-P (eds) Abolishing User Fees for Patients in West Africa: Lessons for Public Policy. Paris: AFD, Paris. http://recherche.afd.fr, pp. 53-76.

Touré L (2015) User fee exemption policies in Mali: sustainability jeopardized by the malfunctioning of the health system. BMC Health Services Research 15(3): 1-12. DOI: 10.1186/1472-6963-15-S3-S8.

True JL, Jones BD and Baumgartner FR (2007) Punctuated equilibrium theory: explaining stability and change in public policymaking. In: Theories of the Policy Process. 2nd ed. Boulder, Colo.: Westview Press, pp. 155-188.

Umeh CA (2018) Challenges toward achieving universal health coverage in Ghana, Kenya, Nigeria, and Tanzania. The International Journal of Health Planning and Management. DOI: 10.1002/hpm.2610.

Yin RK (2009) Case Study Research: Design and Methods. 4th ed. Applied social research methods series 5. Los Angeles, Calif.: Sage Publications. 